\title{
Long Noncoding RNA Sox2 Overlapping Transcript (SOX2OT) Promotes Non-Small-Cell Lung Cancer Migration and Invasion via Sponging microRNA I 32 (miR-I32) [Retraction]
}

\author{
Zhang K, Li Y, Qu L, Ma X, Zhao H, Tang Y. Onco \\ Targets Ther. 2018;11:5269-5278.
}

The Editor and Publisher of OncoTargets and Therapy wish to retract the published article. Concerns were raised over the alleged image duplication of images in Figure 2A and Figure 2C, and the alleged duplication of images in Figure $2 \mathrm{C}$ with similar images from an unrelated article, specifically:

- Figure 2A, panel A549 0h si-NC appears to show duplicated elements with panel H1299 0h si-NC; panel A549 0h si-SOX2OT appears to show duplicated elements with panel H1299 0h si-SOX2OT; panel H1299 0h si-SOX2OT appears to show duplicated elements with panel H1299 24h si-SOX2OT.
- Figure 2C, panels Vimentin and GAPDH appear to have been duplicated in Figure 3D from Tong et al, 2017 (DOI: 10.3892/etm.2017.5169).

The authors did not respond to our queries and the Editor determined the findings of the study were no longer valid and advised for the article to be retracted.

Our decision-making was informed by our policy on publishing ethics and integrity and the COPE guidelines on retraction.

The retracted article will remain online to maintain the scholarly record, but it will be digitally watermarked on each page as "Retracted".

\section{Publish your work in this journal}

OncoTargets and Therapy is an international, peer-reviewed, open access journal focusing on the pathological basis of all cancers, potential targets for therapy and treatment protocols employed to improve the management of cancer patients. The journal also focuses on the impact of management programs and new therapeutic agents and protocols on patient perspectives such as quality of life, adherence and satisfaction. The manuscript management system is completely online and includes a very quick and fair peer-review system, which is all easy to use. Visit http://www.dovepress.com/ testimonials.php to read real quotes from published authors. 